This is an open access article under the CC-BY-SA license (https://creativecommons.org/licenses/by-sa/4.0/) ISSN 2355-6102 (print), ISSN 2502-0404 (online)

\title{
KANDUNGAN LEMAK KULIT PADA BERBAGAI JENIS AYAM KONSUMSI
}

\author{
Reni Rakhmawati ${ }^{1}$, Mei Sulistyoningsih ${ }^{2}$ \\ Program Studi Pendidikan Biologi, Fakultas Pendidikan Matematika Ilmu Pengetahuan Alam dan \\ Teknologi Informasi, Universitas PGRI Semarang. \\ Jl. Sidodadi Timur Nomor 24 - Dr. Cipto Semarang, Jawa Tengah 50125. \\ ${ }^{1)}$ Email: rahmamashuri@yahoo.co.id
}

Diterima 13 Agustus 2019, Disetujui 3 September 2019

\begin{abstract}
The fat content has been known to vary so that the physical quality of meat is largely determined by its fat content. The purpose of this study was to determine the skin fat content of various types of chicken consumption. The study was conducted for 1 day at the AsriPlamongan Indah Semarang Housing, and UNDIP's animal husbandry laboratory to examine the skin fat content. The research subjects consisted of 12 chickens consisting of 3 broilers, 3 laying hens, 3 native chickens, 3 male chickens. The research variable is skin fat. The data obtained were analyzed using 5\% ANOVA. The results of the study had a significant effect $(P>0.05)$ of 4 types of chicken on skin fat. Conclusion The fat content of chicken skin in various types of chicken consumption has different levels.
\end{abstract}

Keywords: Chicken, Skin fat

\section{PENDAHULUAN}

Kulit unggas berfungsi melindungi permukaan tubuh secara mekanik terdapat kemungkinan memasukan zat-zatnya, mengatur temperatur tubuh, sebagai kelenjar sekresi yaitu keluarnya keringat, tempat berlangsungnya respirasi. Kulit mempunyai kelenjar minyak yang terdapat pada pangkal ekor (Koswara, 2009).

Struktur dan komposisi kimia kulit unggas secara histologis, kulit hewan pada umumnya dapat dibagi menjadi tiga yaitu lapisan epidermis, dermis (korium) dan hipodermis (subkutis). Lapisan epidermis adalah lapisan luar kulit yang tersusun dari lapisan epitel. Sel-sel epitel ini tidak hanya tumbuh menjadi epidermis, tetapi juga merupakan protein yang disebut keratin. Lapisan dermis terdiri dari jaringan serat kolagen yang dibangun oleh tenunan pengikat. Lapisan hipodermis berfungsi pokok sebagai batas antara tenunan kulit dan tenunan daging. Lapisan kulit unggas umumnya bersifat longgar, terdapat banyak tenunan lemak dan pembuluh-pembuluh darah (Judoamidjoyo, 1981).
Lemak pada ayam menyebar dibawah kulit, hanya sedikit yang terdapat dibawah daging (Wahyu 1997). Pembentukan lemak kulit terjadi adanya kandungan energi yang digunakan dalam tubuh berasal dari karbohidrat dan cadangan lemak (Meliandasari, 2013).Tujuan penelitian adalah menguji kandungan lemak kulit pada berbagai jenis daging ayam konsumsi. Penelitan ini bermanfaat untuk memberikan informasi kepada masyarakat mengenai kandungan lemak kulit yang terdapat pada berbagai jenis ayam konsumsi, hasil penelitian dapat digunakan sebagai acuan untuk penelitian berikutnya.

\section{METODE PENELITIAN}

\section{Waktu dan Tempat Penelitian}

Penelitian ini dilaksanakan pada bulan Desember 2018 di Plamongan Indah Kota Semarang.

\section{Subjek Penelitian}

Subjek penelitian adalah empat jenis ayam konsumsi yang terdiri dari ayam broiler umur 5 minggu, ayam pejantan umur 8 minggu, ayam kampung umur 24 minggu, dan ayam merah 96 minggu. 
Alat dan Bahan Penelitian

Alat yang digunakan dalam penelitian ini adalah plastik, timbangan, pisau, label nama, baskom, tampah. Bahan yang digunakan dalam penelitian adalah kulit ayam broiler umur 5 minggu, kulit ayam pejantan umur 8 minggu, kulit ayam kampung umur 24 minggu, kulit ayam merah umur 96 minggu.

Rancangan Penelitian
Materi penelitian terdiri 4 perlakuan dengan 3 pengulangan. Setiap jenis ayam diambil 3 ulangan sehingga jumlah total sampel penelitian semuanya 12 ekor ayam. Variabel yang diteliti adalah kandungan lemak kulit pada berbagai jenis ayam konsumsi.

\section{HASIL DAN PEMBAHASAN}

Hasil penelitian persentase lemak kulit ayam konsumsi seperti pada Tabel 1 .

Tabel 4.1 Persentase lemak kulit pada berbagai jenis ayam konsumsi

\begin{tabular}{lccccc}
\hline Perlakuan & \multicolumn{3}{c}{ Ulangan Ke- } & $\begin{array}{c}\text { Jumlah } \\
\text { Perlakuan } \\
(\mathrm{T})\end{array}$ & $\begin{array}{c}\text { Rataan } \\
\text { perlakuan }\end{array}$ \\
\cline { 2 - 5 } & 1 & 2 & 3 & 31,82 & $10,60^{\mathrm{a}}$ \\
\hline $\mathrm{P} 1$ & 11,25 & 10,03 & 10,54 & 29,14 & $9,71^{\mathrm{ab}}$ \\
$\mathrm{P} 2$ & 9,77 & 9,81 & 9,56 & 23,02 & $7,67^{\mathrm{c}}$ \\
$\mathrm{P} 3$ & 7,10 & 6,23 & 9,69 & $8,03^{\mathrm{bc}}$ \\
$\mathrm{P} 4$ & 8,01 & 8,45 & 7,65 & 24,11 & 9 \\
\hline Jumlah Ulangan & 36,13 & 34,52 & 37,44 & 108,09 & \\
\hline Rataan Umum & & & & & \\
Keterangan : & & & & \\
$\mathrm{P}_{1} \quad$ : Ayam boiler & & & & \\
$\mathrm{P}_{2} \quad$ : Ayam merah & & & & \\
$\mathrm{P}_{3} \quad$ : Ayam kampung & & & & & \\
$\mathrm{P}_{4} \quad$ : Ayam pejantan & & & & &
\end{tabular}

Superskrip pada tabel 1 bahwa pada kolom yang sama dengan baris berbeda menunjukkan beda nyata $(\mathrm{P}<0,05)$. Ratarata persentase kandungan lemak kulit yang diperoleh yaitu $\mathrm{P} 1=10,60 \%, \mathrm{P} 2=9,71 \%$, $\mathrm{P} 3=7,67 \%$, $\mathrm{P} 4=8,03 \%$. Hasil penelitian menunjukan bahwa terdapat perbedaan kandungan lemak kulit yang terdapat pada keempat jenis ayam konsumsi. Kandungan lemak kulit yang nilainya tertinggi pada P1 yaitu ayam broiler, sedangkan kandungan lemak kulit yang terendah pada P3 yaitu ayam kampung.

Kandungan lemak yang terdapat pada kulit ayam akan berpengaruh juga terhadap kandungan lemak pada daging ayam. Hal ini dibuktikan dari hasil penelitian (Alan, 2019) menunjukan bahwa dari berbagai jenis ayam yaitu ayam broiler, ayam merah, ayam kampung, dan ayam pejantan. Kandungan lemak daging yang tertinggi pada ayam broiler dan kandungan lemak daging yang terendah terdapat pada ayam kampung. Hasil penelitian tersebut sesuai dengan penelitian ini bahwa kandungan lemak kulit pada berbagai jenis ayam tertinggi pada ayam broiler dan kandungan lemak kulit terendah terdapat pada ayam kampung.

Menurut Wahyu (1997) lemak pada ayam menyebar dibawah kulit, hanya sedikit yang dibawah daging. Penimbunan lemak tubuh pada ayam dipengaruhi banyak faktor. Faktor tersebut yaitu strain ayam, jenis kelamin, umur, kualitas ransum, serta faktor lingkungan seperti kandang, musim, temperatur, serta kelembapan. Sejalan dengan Wahyu (1997) Syska, Supratman dan Abun (2009) juga menjelaskan bahwa pakan akan mempengaruhi akumulasi dan penyebaran total lemak kulit ke dalam bagian-bagian tubuh ternak.

Pembentukan lemak kulit terjadi adanya kandungan energi yang digunakan dalam tubuh berasal dari karbohidrat dan cadangan lemak. Meliandasari et al. (2013) juga mengatakan bahwa deposisi lemak 
ayam broiler umumnya disimpan dalam bentuk lemak di rongga perut dan dibawah kulit.

Menurut Mulyani (2003) sumber utama pada pakan broiler adalah karbohidrat dan lemak. Anggorodi (1992) dalam Sri Hartati juga menjelaskan bahwa kandungan lemak dalam tubuh ternak diperoleh dari kelebihan energi yang dikonsumsi. Sehingga semakin tinggi kandungan energi yang dikonsumsi maka akan semakin tinggi juga kandungan lemak dalam tubuh.

Dilihat dari karakteristik ayam broiler menurut Suprijatna et al. (2008) yaitu bersifat tenang, bentuk tubuh besar, pertumbuhan ayam cepat, bulu merapat ke tubuh ternak, kulit ayam putih, dan produksi telur rendah. Dengan karakteristik broiler yang dapat bertumbuh dengan cepat maka ayam akan mengonsumsi pakan lebih banyak sehingga dapat mempengaruhi persentase lemak dalam tubuhnya. Azizah N.A., Mahfudz dan Sunarti (2017) juga menambahkan pertumbuhan ayam broiler yang cepat diikuti oleh pertumbuhan lemak, bobot badan yang tinggi berhubungan dengan penimbunan lemak tubuh yang tinggi pula.

Jenis ayam kampung memiliki rerata kandungan lemak kulit terendah. Menurut (Widiarti, 2014) ayam kampung tidak mempunyai ciri spesifik yang khas, dalam hal ini keragaman fenotip maupun genotipnya. Iswanto (2002) juga menjelaskan bahwa kekurangan dari ayam kampung adalah pertumbuhan dan perkembangannya relatif lambat. Ditambahkan oleh Amlia, Pagala, dan Rahim (2016) bahwa lambatnya pertumbuhan ayam kampung dipengaruhi oleh beberapa faktor, salah satunya adalah faktor genetik. Seperti yang telah dijelaskan bahwa perkembangan ayam akan mempengaruhi konsumsi pakan sehingga akan berpengaruh juga pada penimbunan lemak pada tubuh ayam.

\section{SIMPULAN}

Kesimpulan dari penelitian ini adalah sebagai berikut :

Kandungan lemak kulit pada berbagai jenis ayam konsumsi berpengaruh nyata dengan hasil persentase terendah pada P3 (Ayam kampung) dengan rerata $7,67 \%$ dan hasil persentase tertinggi pada P1 (Ayam broiler) dengan rerata $10,60 \%$.

\section{DAFTAR PUSTAKA}

Abun. (2009). Bahan Ajar Lipid dan Asam Lemak pada Unggas dan Monogastrik. Jatinangor.

Amlia, M. A.Pagala, \&R. Aka. (2016).Studi Karakteristik Sifat Kualitatif dan Kuantitatif Ayam Kampung di Kecamatan Lasalimu Kabupaten Buton. Fakultas Peternakan, Universitas UHO. Sulawesi Tenggara. 1(1): 31-39.

Anggoroadi. (1992). Ilmu Ternak Unggas. Jakarta: PT. Gramedia Pustaka.

Azizah N.A., L.D. Mahfudz, \&D. Sunarti. (2017). Kadar Lemak dan Protein Karkas Ayam Broiler Akibat Penggunaan Tepung Limbah Wortel (Daucus carota L.) dalam Ransum. Jurnal Sain Peternakan Indonesia, 12(4): 389-395.

Iswanto, H. (2002). Ayam Kampung Pedaging. Jakarta: Agro Media Pustaka.

Judoamijoyo, R.M. (1981). Dasar Teknologi dan Kimia Kulit. Departemen Teknologi Hasil Pertanian. Fakultas Teknologi Pertanian. Institut

Pertanian Bogor, Bogor.

Koswara,S. (2009). "Pengolahan Unggas". (On-line).

http://tekpan.unimus.ac.id/wpcontent/uploads/2013/07/PENGOL AHAN-UNGGAS.pdf, diakses 5 April 2019).

Meliandasari, D., L. D. Mahfuds, \& W. Sarengat. (2013). Pengaruh Penggunaan Tepung Rumput Laut (Gracilaria verrucosa) dalam Ransum terhadap Perlemakan 
Ayam Broiler Umur 42 Hari. Animal Agriculture Journal, 2(1): 120-127.

Mulyani, (2003). Buku Ajar Dasar Teknologi Ternak. Semarang: Fakultas Peternakan Universitas Diponegoro.

Suprajitna, E. U., Atmomarsono. R, Kartasudjana. (2008). Ilmu Dasar Ternak Unggas. Jakarta: Penebar Swadaya.

Wahyu, J. (1997). Ilmu Nutrisi Unggas Cetakan Ke-4. Yogyakarta: Gadjah Mada University Press.
Widiarti., R., A. Rahman,\& S., Sudaryati. (2014). Semi Intensive Native Chicken Farming As An Alternative Establish Food Proceeding Seminar Sustainable Livestock Production Based on Local Resource in the Global Climate Change Era : Prospect dan Chalanges. Faculty of Animal Husbandry, 13(2): 59-65. University of Brawijaya. Malang, Indonesia. 